\title{
Land Suitability of Agricultural Crops for Supporting Peat Restoration in South Kalimantan, Indonesia
}

\author{
Abdul Hadi ${ }^{1 *}$, Muhammad Syarbini ${ }^{1}$, Maria Sari L. Panjaitan ${ }^{2}$ \\ ${ }^{1}$ Division of Soil Science, Lambung Mangkurat University, Banjarbaru, Indonesia \\ ${ }^{2}$ Study Program of Agroecotechnology, Lambung Mangkurat University, Banjarbaru, Indonesia
}

\begin{abstract}
Following the release of Presidential Regulation No 1/2016, a peat restoration pilot project has been carried out in Banjarbaru District, South Kalimantan in addition to other two pilot projects in other provinces of Indonesia. The pilot project has been designed to implement the three aspects of peat restoration, namely rewetting, revegetation and revitalization of society. Implementation of revegetation is mainly through applying agroforestry by growing agricultural crops in spaces between trees. The objective of present study was to elucidate the suitability of agricultural crops in area of restoration of degraded peatland in South Kalimantan, Indonesia. The suitability of agricultural crops was studied by collecting rainfall and air temperature data from the climatic station of Syamsudin Noor Airport in Banjarbaru, while the nutrient retentions values were determined in the laboratory. Peat depth and drainage class were determined by direct field observations, while peat decomposition level was classified by quantitative method in the field. All collected data were then used to assess the land suitability class for dry land paddy (Oriza sativa L), long bean (Vigna sinensis ENDL), cucumber (Cucumis sativus LINN), mustard (Brassica rugose FRAIN), orange (Citrus sp), stink bean (Parkia speciose HASSK), rubber (Hevea brassialiansis M.A), and coconut (Cocus $\underline{\text { nocifera }}$ L). The productivity data of long bean, cucumber and mustard were obtained by farmer interview. The results showed that most of the agricultural crops were classified as marginally suitable (Class S3).The main limiting factors of agricultural development in this area are low soil $\mathrm{pH}$, low base saturation and peat ripening. Peat depth limits the development of some crops. The above mentioned limiting factors ought to contribute to the low crop productivities in the area. The limiting factors were less severe for pineapple and stink bean, indicating that these crops have potential to be grown along with trees for restoration efforts in the area.
\end{abstract}

Key words: land suitable classification, peat restoration, south Kalimantan.

\section{INTRODUCTION}

Peat soils are defined as the soils that contain appreciable amount of organic matter dominating the soil properties (Mathur and Farham, 1985). About $14.9 \mathrm{~m}$ ha of this soil type occurs in Indonesia, of which about 280,000 ha is in South Kalimantan. Peat soil in Indonesia has both economical and environmental values, especially for agricultural-based activities and carbon storage, respectively (Noor, 2010).

Due to its high organic matter content, peat soils are prone to fires (Charmenta at al., 2015; Warrant et al., 2017). Severe forest fires in

Corresponding Author: Prof. Dr. Abdul Hadi, Soil Science Division, Lambung Mangkurat University, Jl. A. Yani KM 36, Banjarbaru, Indonesia, Email: abdhadi@ulm.ac.id Journal of Wetlands Environmental Management Vol 7, No 2 (2018) 115 - 122 http://dx.doi.org/10.20527/jwem.v6i2.187
2015 led President Joko Widodo to release Presidential Regulation (No 1/2016) for Peat Restoration Agency of Indonesia (In Indonesian: Badan Restorasi Gambut, BRG). According to the regulation, the task of BRG is to coordinate and facilitate peat restoration in Riau, Jambi, South Sumatera, Central Kalimantan, West Kalimantan, South Kalimantan and Papua provinces covering an area of $2 \mathrm{~m}$ ha in five years. The BRG is led by a Director and equipped with a secretary and five deputies, including deputy for research and development.

Following the release of presidential regulation, the BRG developed a National Action Plan and released necessary standard operation procedures for its implementation. 

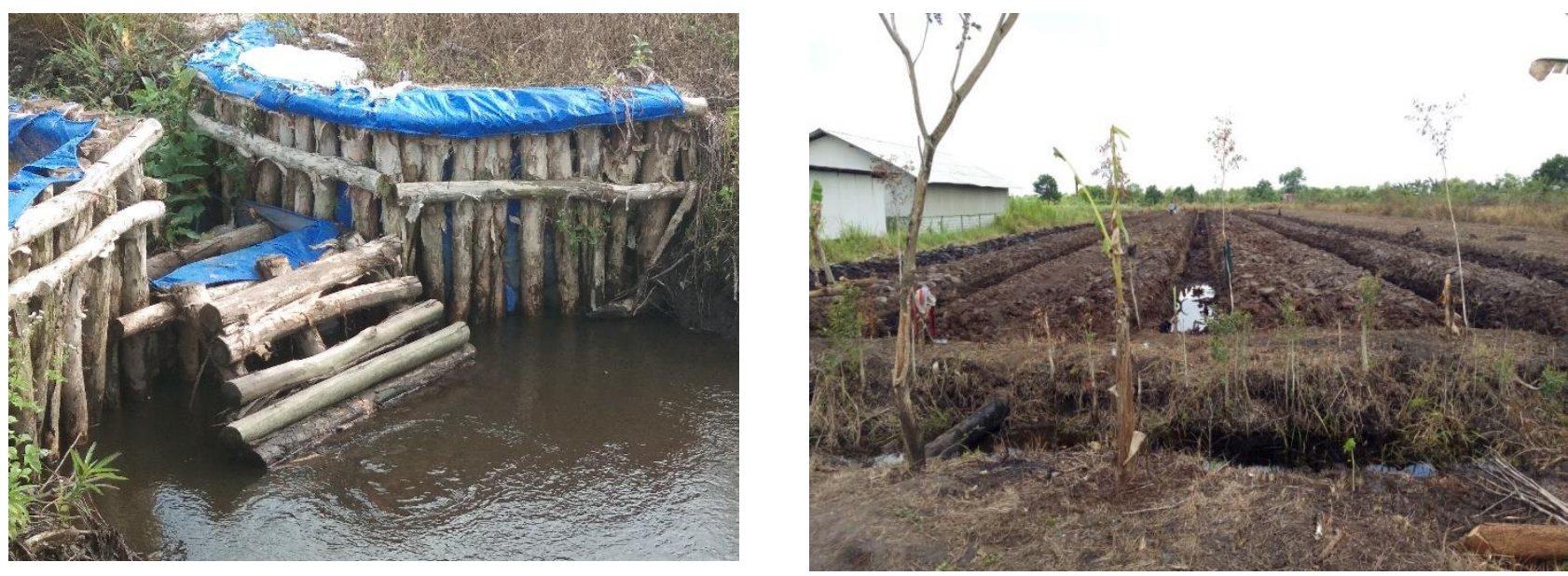

Figure 1. Wooden water gate (left) and canals at farm site (right)

The Plan includes the target of $2 \mathrm{~m}$ ha peat restoration in five provinces of which 200,000 ha peat restoration is to be carried out in South Kalimantan. The restoration task is supervised by five deputies of BRG. Among them, the research and development deputy is responsible for 35 research activities and five pilot projects. Execution of the projects has been maintained to be in line with other regulations, especially Governmental Regulation Number 71/2014 and Governmental Regulation Number 57/2016 that are on Protection and Management of Peatland Ecosystems.

Among the five pilot projects, Lambung Mangkurat University is responsible for one pilot project entitled, 'Pilot Project on Integrated Restoration of Degraded Peatlands in Liang Anggang Conserved Forest'. The project covers an area of 15 ha, present within the 960 ha conserved forest in Banjarbaru District, South Kalimantan. The conserved forest status of the area is bestowed upon by Ministry of Forestry (Decision Number 434/Kpts-II/1996). The area is near Syamsudin Noor, the largest airport in South Kalimantan, and only about $20 \mathrm{~km}$ from the

Journal of Wetlands Environmental Management Vol 7, No 2 (2019) 115 - 122 http://dx.doi.org/10.20527/jwem.v7i2.187
Banjarmasin city. Due to its strategic location, about half of the area has been used for farmer-based activities and resettlement. Irrigation canal and road are also present within this area (Hadi et al., 2017).

Under the pilot projects, the peat restoration plan mainly includes three kinds of activities, namely (1) rewetting, revegetation, and (3) revitalization of society. For the integrated pilot project, Lambung Mangkurat University has also focused on integrating these three aspects in fast two years, though the technologies applied are less-expensive and simple. Rewetting has been done by contracting wooden water gate equipped with sand-filled bag to adjust the required gate height. Canals have also been constructed to control the water table at farm level (Figure 1). Small portion of the studied area has been cultivated by mustard and pine apple. Most of the area remained as scrub and grasslands. Implementation of revegetation is mainly through applying agroforestry, i.e. growing agricultural crops in between tree. The tree species introduced in the project area are Balangeran (Sore Balangeran), Stink bean 
(Parkia spesiosa), and Jelutung (Dyra lowii Hook F.) (Hadi et al., 2017).

Development of agricultural crops in the area has been mainly based on market demand, and the environmental considerations have got less attention by farmers. Peatlands in Landasan Ulin Utara district, for example, have been mainly cultivated to vegetable fields which have high economic values. Vegetable crops require high application of fertilizers, including organic fertilizer. Application of fresh organic matter enhances microbial respiration releasing more carbon dioxide $\left(\mathrm{CO}_{2}\right)$, a precursor of global warming (Hadi et al. 2001). Practicing appropriate cultivation management on given crop may minimize the production and/or emissions of $\mathrm{CO}_{2}$ which further is in line with the peat restoration effort.

There are few studies on the suitability of agricultural crops prior to selection of corps to grown in the area. Moreover, the information of $\mathrm{CO}_{2}$ upon the peat restoration efforts are also scares. The objective of present study was to elucidate the suitability of agricultural crops for agroforestry used for restoration of degraded peat in South Kalimantan, Indonesia.

\section{METHODOLOGY}

To study the land suitability for agricultural crops, rainfall and air temperature data were obtained from the climatic station of Syamsudin Noor Airport in Banjarbaru District, South Kalimantan (Figure 2). Field survey was carried out to collect soil samples from the area. Fifteen soil samples were taken from $0-30 \mathrm{~cm}$ soil depth and brought to laboratory for determination of the nutrient retentions by methods described by Page at al.

Journal of Wetlands Environmental Management

Vol 7, No 2 (2019) 115 - 122

http://dx.doi.org/10.20527/jwem.v7i2.187

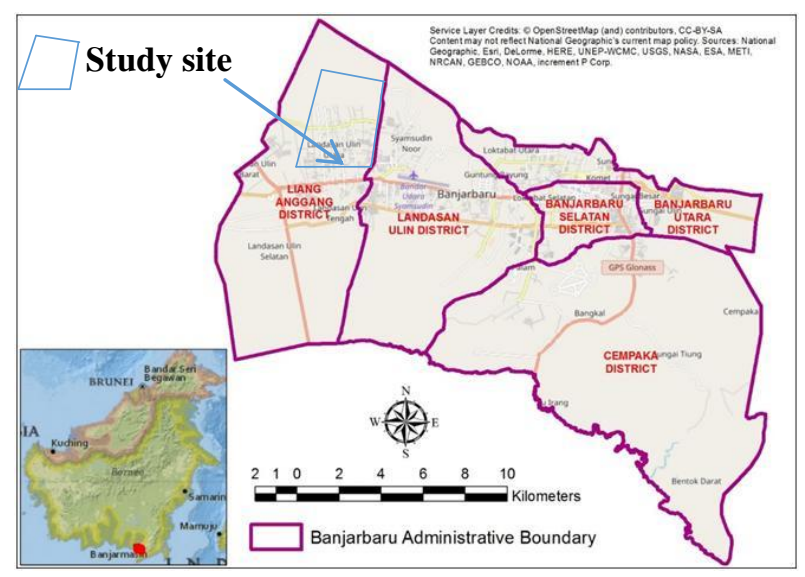

Figure 2. Map of study area (modified from Syam'ani et al., 2018).

(1982). Peat depth and drainage class were determined by direct field observation. Soil $\mathrm{pH}$ was determined following shaking the soil with deionized water at ratio of 1:5, while organic carbon content was determined by Wikley-Black method. Soil phosphorus was determined by Trough and Bray II method with procedures described by Page al al. (1982).

All collected data were then used to assess the land suitability classes for dry land paddy ( Oriza sativa $\mathrm{L}$ ), long bean (Vigna sinensis ENDL), cucumber (Cucumis sativus LINN), mustard (Brassica rugose FRAIN), orange (Citrus sp), stink bean (Parkia speciose HASSK), rubber ( Hevea brassialiansis M.A), and coconut (Cocus nocifera $\mathrm{L}$ ). The 93 criteria were based on Djaenuddin et al. (2003; Table 1).

To study carbon dioxide $\left(\mathrm{CO}_{2}\right)$ emission from given crops as affected by soil ameliorants, soil samples were taken from scrub field, grass field, mustard cultivated field and pineapple cultivated field. Soil samples were mixed with either rice-husk biochar or furnace sledge at the rate of 2 ton $\mathrm{ha}^{-1}$. A portion of each soil sample was kept without 
Table 1. Crop requirements for mustard, long bean, cucumber, rain fed paddy, pineapple, stink bean, coconut, and rubber.

\begin{tabular}{|c|c|c|c|c|c|c|c|c|c|c|}
\hline \multicolumn{3}{|c|}{ Land characteristics } & \multirow[t]{2}{*}{ Mustard } & \multirow{2}{*}{$\begin{array}{l}\text { Long } \\
\text { bean }\end{array}$} & \multirow{2}{*}{$\begin{array}{l}\text { Cucum- } \\
\text { ber }\end{array}$} & \multirow{2}{*}{$\begin{array}{l}\text { Rain fed } \\
\text { paddy }\end{array}$} & \multirow[t]{2}{*}{ Pineapple } & \multirow[t]{2}{*}{ Stink bean } & \multirow[t]{2}{*}{ Coconut } & \multirow[t]{2}{*}{ Rubber } \\
\hline Code & Name & Class & & & & & & & & \\
\hline \multirow{4}{*}{$\begin{array}{l}\text { Temp- } \\
\text { erature, tr }\end{array}$} & \multirow{4}{*}{$\begin{array}{l}\text { Temp- } \\
\text { erature, } \\
{ }^{\circ} \mathrm{C}\end{array}$} & & & & & & & & & \\
\hline & & $\mathrm{S} 1$ & $18-25$ & $14-20$ & $12-24$ & $24-29$ & $17-20$ & $18-25$ & $26-30$ & $25-28$ \\
\hline & & $\mathrm{S} 2$ & $25-30$ & $20-23$ & $24-27$ & $29-32$ & $20-30$ & $25-30$ & $30-34$ & $28-32$ \\
\hline & & S3 & $30-35$ & $23-25$ & $27-30$ & $32-35$ & $30-35$ & $30-35$ & & $32-35$ \\
\hline \multirow{4}{*}{$\begin{array}{l}\text { Water avai- } \\
\text { lability, wa }\end{array}$} & \multirow{4}{*}{$\begin{array}{l}\text { Rainfall, } \\
\text { mm year- } \\
1\end{array}$} & $\mathrm{~N}$ & $>35$ & $>25$ & $>30$ & $>35$ & $>35$ & $>35$ & & $>35$ \\
\hline & & $\mathrm{S} 1$ & $1000-2500$ & $350-600$ & $350-600$ & $500-1800$ & $1000-2000$ & $1000-2000$ & $2500-3000$ & $2000-3000$ \\
\hline & & $\mathrm{S} 2$ & $2500-4000$ & $600-800$ & $600-1000$ & $1800-2400$ & $2000-3000$ & $2000-3000$ & $3000-3500$ & $3000-4000$ \\
\hline & & S3 & $4000-6000$ & $800-1000$ & $>1000$ & $2400-2800$ & $3000-4000$ & $3000-6000$ & $3500-4000$ & $4000-5000$ \\
\hline \multirow{4}{*}{$\begin{array}{l}\text { Oxygen } \\
\text { availability, } \\
\text { oa }\end{array}$} & \multirow[t]{4}{*}{ Drainage } & $\mathrm{N}$ & $>6000$ & $>1000$ & $<350$ & $\begin{array}{l}>2800 \\
<500\end{array}$ & $>4000$ & $>6000$ & $>4000$ & $>5000$ \\
\hline & & $\mathrm{S} 1$ & Moderate & $\begin{array}{l}\text { Good; } \\
\text { Slightly } \\
\text { restricted }\end{array}$ & $\begin{array}{l}\text { Good; } \\
\text { Slightly } \\
\text { restricted }\end{array}$ & $\begin{array}{l}\text { Restrict- } \\
\text { ed, } \\
\text { slightly } \\
\text { restricted }\end{array}$ & Moderate & Moderate & Good & Mode-rate \\
\hline & & $\mathrm{S} 2$ & Restricted & $\begin{array}{l}\text { Slightly } \\
\text { quick; } \\
\text { Moderate }\end{array}$ & $\begin{array}{l}\text { Slightly } \\
\text { quick; } \\
\text { Moderate }\end{array}$ & $\begin{array}{l}\text { Slightly } \\
\text { quick, } \\
\text { moderate }\end{array}$ & $\begin{array}{c}\text { Restrict- } \\
\text { ed }\end{array}$ & Slow & Moderate & Restricted \\
\hline & & S3 & $\begin{array}{l}\text { Slightly } \\
\text { quick }\end{array}$ & $\begin{array}{l}\text { Restrict- } \\
\text { ed }\end{array}$ & $\begin{array}{l}\text { Restrict- } \\
\text { ed }\end{array}$ & $\begin{array}{c}\text { Very } \\
\text { restricted }\end{array}$ & $\begin{array}{l}\text { Restrict- } \\
\text { ed, } \\
\text { Slighly } \\
\text { quick }\end{array}$ & $\begin{array}{c}\text { Slow,slightl } \\
\text { y quick }\end{array}$ & $\begin{array}{l}\text { Slightly slow, } \\
\text { slow, slightly } \\
\text { quick }\end{array}$ & $\begin{array}{l}\text { Slightly } \\
\text { quick }\end{array}$ \\
\hline Root zone & Peat & $\mathrm{N}$ & $\begin{array}{l}\text { Very } \\
\text { restricted; }\end{array}$ & $\begin{array}{l}\text { Very } \\
\text { restricted }\end{array}$ & $\begin{array}{l}\text { Very } \\
\text { restricted }\end{array}$ & Quick & $\begin{array}{l}\text { Very } \\
\text { restricted }\end{array}$ & $\begin{array}{l}\text { Very slow; } \\
\text { Quick }\end{array}$ & $\begin{array}{l}\text { Very slow; } \\
\text { Quick }\end{array}$ & $\begin{array}{l}\text { Very } \\
\text { restricted; }\end{array}$ \\
\hline
\end{tabular}

Journal of Wetlands Environmental Management

Vol 7, No 2 (2019) 115 - 122

http://dx.doi.org/10.20527/jwem.v7i2.187 


\begin{tabular}{|c|c|c|c|c|c|c|c|c|c|c|}
\hline \multirow[t]{8}{*}{ condition, rc } & \multirow{4}{*}{$\begin{array}{l}\text { depth, } \\
\mathrm{cm}\end{array}$} & \multicolumn{2}{|r|}{ Quick } & \multirow{2}{*}{$\frac{\text {; Quick }}{<60}$} & \multirow{2}{*}{$\frac{\text {; Quick }}{<60}$} & \multicolumn{3}{|c|}{; Quick } & \multicolumn{2}{|r|}{ Quick } \\
\hline & & S1 & $<60$ & & & $<60$ & $<60$ & $<60$ & $<60$ & $<60$ \\
\hline & & S2 & $60-140$ & $60-140$ & $60-140$ & $60-140$ & $60-140$ & $60-140$ & $60-140$ & $60-140$ \\
\hline & & S3 & $140-200$ & $140-200$ & $140-200$ & $140-200$ & $140-200$ & $140-200$ & $140-200$ & $140-200$ \\
\hline & \multirow[b]{7}{*}{$\begin{array}{l}\text { Cation } \\
\text { exchange } \\
\text { able } \\
\text { capacity, } \\
\text { cmol }\end{array}$} & $\mathrm{N}$ & $>200$ & $>200$ & $>200$ & $>200$ & $>200$ & $>200$ & $>200$ & $>200$ \\
\hline & & S1 & Sapric & Sapric & Sapric & Sapric & Sapric & Sapric & Sapric & Sapric \\
\hline & & S2 & $\begin{array}{l}\text { Sapric; } \\
\text { hemik }\end{array}$ & $\begin{array}{l}\text { Sapric; } \\
\text { hemik }\end{array}$ & $\begin{array}{l}\text { Sapric; } \\
\text { hemik }\end{array}$ & $\begin{array}{l}\text { Sapric; } \\
\text { hemik }\end{array}$ & $\begin{array}{l}\text { Sapric; } \\
\text { hemik }\end{array}$ & $\begin{array}{l}\text { Sapric, } \\
\text { Hemic }\end{array}$ & Sapric, Hemic & $\begin{array}{l}\text { Sapric, } \\
\text { Hemic }\end{array}$ \\
\hline & & S3 & $\begin{array}{l}\text { Hemic, } \\
\text { fibric }\end{array}$ & $\begin{array}{l}\text { Hemic, } \\
\text { fibric }\end{array}$ & $\begin{array}{l}\text { Hemic, } \\
\text { fibric }\end{array}$ & $\begin{array}{l}\text { Hemic, } \\
\text { fibric }\end{array}$ & $\begin{array}{l}\text { Hemic, } \\
\text { fibric }\end{array}$ & Hemic & Hemic & Hemic \\
\hline \multirow{12}{*}{$\begin{array}{l}\text { Nutrient } \\
\text { retention, nt }\end{array}$} & & $\mathrm{N}$ & Fibric & Fibric & Fibric & Fibric & Fibric & Fibric & Fibric & Fibric \\
\hline & & S1 & $>16$ & $>16$ & $>16$ & $>16$ & $>16$ & $>16$ & - & - \\
\hline & & S2 & $<16$ & $<16$ & $<16$ & $<16$ & $<16$ & $<16$ & - & - \\
\hline & \multirow{3}{*}{$\begin{array}{l}\text { Base } \\
\text { satura- } \\
\text { tion, \% }\end{array}$} & S3 & - & - & - & - & - & & - & - \\
\hline & & S1 & $>35$ & $>35$ & $>50$ & $>50$ & $>50$ & $>35$ & $<35$ & $>20$ \\
\hline & & S2 & $20-35$ & $20-35$ & $35-50$ & $35-50$ & $35-50$ & $20-35$ & $35-50$ & $<20$ \\
\hline & \multirow{3}{*}{$\mathrm{pH}$} & S3 & $<20$ & $<20$ & $<35$ & $<35$ & $<35$ & $<20$ & $>50$ & - \\
\hline & & S1 & $5.5-7.8$ & $6.0-7.5$ & $5.6-7.6$ & $5.6-7.6$ & $5.5-7.3$ & $5.5-7.8$ & $5.0-6.0$ & $5.2-7.5$ \\
\hline & & S2 & $5.0-5.5$ & $5.8-6.0$ & $5.4-5.6$ & $5.4-5.6$ & $5.0-5.5$ & $5.0-5.5$ & $4.5-5.0$ & $4.8-5.2$ \\
\hline & \multirow{3}{*}{$\begin{array}{l}\text { C- } \\
\text { organic }\end{array}$} & S3 & $<5.0$ & $<5.8$ & $<5.4$ & $<5.4$ & $<5.0$ & $<5.0$ & $<4.5$ & $<4.8$ \\
\hline & & S1 & $>1.2$ & $>1.2$ & $>1.2$ & $>1.2$ & $>1.2$ & $>1.2$ & $>0.8$ & $>0.8$ \\
\hline & & S2 & $0.8-1.2$ & $0.8-1.2$ & $0.8-1.2$ & $0.8-1.2$ & $0.8-1.2$ & $0.8-1.2$ & $<0.8$ & $<0.8$ \\
\hline
\end{tabular}


biochar and furnace sledge, and was considered as the control treatment. Twenty gram of soil samples were transferred in to three $250 \mathrm{~mL}$ glass jars (nine jars for each crop). A $25 \mathrm{~mL}$ jar containing $10 \mathrm{~mL} \mathrm{NaOH}$ was inserted to each jar. The jars were then air-sealed and arranged according to Completely Randomized Experimental Design. The jars were opened one week after the jar closure, and the remaining $\mathrm{NaOH}$ was titrated by $\mathrm{HCl}$. The $\mathrm{CO}_{2}$ emissions were calculated based on method described by as follows (Bloem at al., 2006).

$\mathrm{CO}_{2}(\mathrm{~g})=\frac{\left(\begin{array}{c}\text { Blank titer }- \text { Sample titer }) \times \mathrm{N} \\ \mathrm{HCl} \times 10 / 5 \times 12 \times 1000\end{array}\right.}{\text { Soil dry weight }}$

Collected data were averaged and compared with the crop requirements presented in Table 1.

The $\mathrm{CO}_{2}$ data were tested for normality prior to analysis of variance (ANOVA). Least significant test was carried out to elucidate effect of land cover changes and soil ameliorant on $\mathrm{CO}_{2}$ emissions. All statistical analyses were based on procedure described by Mattjik and Sumertajaya (2002).

\section{RESULTS AND DISCUSSION}

\section{Land Suitability of Agricultural Crops}

The characteristics of studied area are presented in column (3) of Table 2. Based on climatology station in Syamsudin Noor airport, the ten years averaged air temperature and precipitation of the area were $27^{\circ} \mathrm{C}$ and

Journal of Wetlands Environmental Management Vol 7, No 2 (2019) 115 - 122 http://dx.doi.org/10.20527/jwem.v7i2.187
2,740 $\mathrm{mm} /$ year, respectively. The averaged peat depth of the area was $110 \mathrm{~cm}$ with organic carbon content of $28.4 \%(\mathrm{w} / \mathrm{w})$. Meanwhile, the cation exchange capacity, base saturation and $\mathrm{pH}$ were $6.1 \mathrm{me} 100 \mathrm{~g}^{-1}, 12.9$ cmol $100 \mathrm{~g}^{-1}$, and 4.8 , respectively. Phosphorous content was (Table 2).

Most of the land in the study area were only marginally suitable (class S3) for studied agricultural crops (Table 2) at its present conditions. However, the area was not suitable for mustard (class $\mathrm{N}$ ). The main limiting factors of agricultural development in this area are low soil $\mathrm{pH}$, low base saturation and low phosphorus content. The above-mentioned limiting factors ought to contribute to the low crop productivity in the area-for example: productivity of mustard is only $4.0 \mathrm{t} \mathrm{ha}^{-1}$ in this area, in comparison to $10 \mathrm{t} \mathrm{ha}^{-1}$ in other areas. Since the limiting factor for mustard development is excessive precipitation which is difficult to be overcame, the potential land suitability for mustard remain unchanged (i.e. class $\mathrm{N}$ ).

The limiting factors are less severe for pine apple and stink bean because the limiting factors are relatively easy to be overcome with present technologies. This indicated that these crops have potential to be grown along with tree for restoration efforts. By applying lime and/or fertilizers the land suitability for stink bean can potentially be improved from S3nr class to S2trrc class. Similarly, constructing surjan (a land that comprises of risen and sunken bed) can increase land suitability for pine apple from S3aonr class to S2trrt class because surjan can improve availability of oxygen in the root zone of plants. Surjan is a 
Table 2. Land suitability classes of studied crops

\begin{tabular}{|c|c|c|c|c|c|c|c|c|c|c|}
\hline \multicolumn{3}{|l|}{ Land characteristics } & \multirow[t]{2}{*}{ Mustard } & \multirow{2}{*}{$\begin{array}{l}\text { Long } \\
\text { bean }\end{array}$} & \multirow{2}{*}{$\begin{array}{l}\text { Cucum- } \\
\text { ber }\end{array}$} & \multirow{2}{*}{$\begin{array}{l}\text { Dry land } \\
\text { paddy }\end{array}$} & \multirow[t]{2}{*}{ Pineapple } & \multirow{2}{*}{$\begin{array}{l}\text { Stink } \\
\text { bean }\end{array}$} & \multirow[t]{2}{*}{ Coconut } & \multirow[t]{2}{*}{ Rubber } \\
\hline Code & Name & Values & & & & & & & & \\
\hline (1) & (2) & (3) & (4) & (5) & (6) & (7) & (8) & (9) & (10) & (11) \\
\hline Temperature, tr & Temperature & $27^{\circ} \mathrm{C}$ & $\mathrm{S} 2$ & $\mathrm{~S} 2$ & $\mathrm{~S} 1$ & $\mathrm{~S} 1$ & $\mathrm{~S} 2$ & $\mathrm{~S} 2$ & $\mathrm{~S} 1$ & S1 \\
\hline $\begin{array}{l}\text { Water avai- } \\
\text { lability, wa }\end{array}$ & Rainfall & $2,740 \mathrm{~mm}$ year- 1 & N1 & S3 & S3 & S3 & $\mathrm{S} 2$ & $\mathrm{~S} 2$ & S1 & S1 \\
\hline $\begin{array}{l}\text { Oxygen } \\
\text { availability, oa }\end{array}$ & Drainage & Moderately rapid & $\mathrm{S} 2$ & $\mathrm{~S} 2$ & $\mathrm{~S} 2$ & $\mathrm{~S} 2$ & $\mathrm{~S} 3$ & $\mathrm{~S} 2$ & $\mathrm{~S} 2$ & $\mathrm{~S} 1$ \\
\hline \multirow[t]{2}{*}{ Root condition, rc } & Peat depth & $110 \mathrm{~cm}$ & $\mathrm{~S} 3$ & S3 & $\mathrm{S} 3$ & $\mathrm{~S} 3$ & $\mathrm{~S} 2$ & $\mathrm{~S} 2$ & $\mathrm{~S} 2$ & $\mathrm{~S} 2$ \\
\hline & Peat ripening & Hemic & & & & & $\mathrm{S} 2$ & $\mathrm{~S} 2$ & $\mathrm{~S} 2$ & $\mathrm{~S} 2$ \\
\hline \multirow[t]{4}{*}{$\begin{array}{l}\text { Nutrient retention, } \\
\mathrm{nr}\end{array}$} & $\begin{array}{l}\text { Cation } \\
\text { exchangeable } \\
\text { capacity }\end{array}$ & $6.1 \mathrm{me} 100 \mathrm{~g}-1$ & $\mathrm{~S} 2$ & $\mathrm{~S} 1$ & $\mathrm{~S} 2$ & $\mathrm{~S} 1$ & $\mathrm{~S} 1$ & $\mathrm{~S} 1$ & $\mathrm{~S} 1$ & $\mathrm{~S} 2$ \\
\hline & Base saturation & $12.9 \mathrm{cmol} 100 \mathrm{~g}-1$ & $\mathrm{~S} 3$ & $\mathrm{~S} 2$ & $\mathrm{~S} 3$ & S3 & $\mathrm{S} 3$ & $\mathrm{~S} 3$ & $\mathrm{~S} 1$ & $\mathrm{~S} 2$ \\
\hline & $\mathrm{pH}$ & 4.8 & S3 & $\mathrm{S} 3$ & S3 & $\mathrm{S} 1$ & S3 & S3 & S1 & $\mathrm{S} 2$ \\
\hline & C-organic & $28.4 \%$ & $\mathrm{~S} 1$ & $\mathrm{~S} 1$ & $\mathrm{~S} 1$ & $\mathrm{~S} 1$ & $\mathrm{~S} 1$ & $\mathrm{~S} 1$ & $\mathrm{~S} 1$ & $\mathrm{~S} 1$ \\
\hline \multirow{2}{*}{$\begin{array}{l}\text { Over all } \\
\text { parameters }\end{array}$} & Actual land class & & N1 & S3renr & S3warc & S3wanr & S3aonr & S3nr & S2aorc & S2renr \\
\hline & Potential land cla & & N1 & S3renr & S3warc & S3wanr & S2trrc & S2trrc & S2rc & S2rc \\
\hline
\end{tabular}

Note: S1, very suitable; S2, moderately suitable; S3, slightly suitable; N, not suitable 
common land development technique by Banjarese tribe in South Kalimantan and other provinces in Indonesia (Hadi et al., 1999). Constructing surjan, along with the application of lime and fertilizers can also improve the land suitability for coconut palm and rubber. However, their suitability classes (i.e. S2 classes) will not be increased since there is unchangeable peat depth and peat ripening as limiting factors.

\section{Mitigation Option for $\mathrm{CO}_{2}$ Emission for Agricultural Crops}

In the study area, the $\mathrm{CO}_{2}$ emissions were affected by land-use changes, but not by soil ameliorant (One-way ANOVA; $\mathrm{F}=$ 4.82, $P<0.01)$. The $\mathrm{CO}_{2}$ emissions were the highest in mustard-cultivated peat land, followed by pine-apple field, scrub field. Grass cultivation in peatland resulted in the lowest $\mathrm{CO}_{2}$ emission (Table 3 ).

Table 3. $\mathrm{CO}_{2}$ emissions from different landcover type.

\begin{tabular}{lcccc}
\hline & Biochar & Slage & Control & $\begin{array}{c}\text { Ameliorant's } \\
\text { mean }\end{array}$ \\
\hline Mustard & 740.0 & 986.7 & 884.7 & $\mathbf{8 7 0 . 4}^{\mathbf{A}}$ \\
\hline $\begin{array}{l}\text { Pine } \\
\text { apple }\end{array}$ & 418.4 & 418.4 & 177.8 & $\mathbf{3 3 8 . 2}^{\mathbf{D}}$ \\
\hline $\begin{array}{l}\text { Grass } \\
\text { field }\end{array}$ & 348.2 & 96.7 & 754.5 & $\mathbf{3 9 9 . 8}^{\mathbf{C}}$ \\
\hline Scrub & 570.3 & 247.3 & 553.3 & $\mathbf{4 5 7 . 0}^{\mathbf{B}}$ \\
\hline $\begin{array}{l}\text { Crop's } \\
\text { mean }\end{array}$ & $\mathbf{5 1 9 . 2}^{\mathbf{a}}$ & $\mathbf{4 3 7 . 3}^{\mathbf{a}}$ & $\mathbf{5 9 2 . 6}^{\mathbf{a}}$ & \\
\hline
\end{tabular}

Note: Means followed by different letters indicate that the values were statistically different at $\mathrm{P}<0.01$ (Fisher's LSD test).

The differences in $\mathrm{CO}_{2}$ emissions from different crops were probably due to the differences in amount and composition of organic matters deposited by crops. Mustard

Journal of Wetlands Environmental Management Vol 7, No 2 (2019) 115 - 122 http://dx.doi.org/10.20527/jwem.v7i2.187 is harvested every three months. leaving a significant amount of root and plant debris in the field. which are subject soil microbial decomposition. The high wax content of pine-apple exudates (Onggo and Astuti. 2005) is not conducive for soil microbial decomposition. In contrary. simple organic matters deposited by mustard encourage the microbial decomposition. resulting in the highest $\mathrm{CO}_{2}$ emissions. Procedures involved in crop harvesting may also contribute to the differences in $\mathrm{CO}_{2}$ emissions. Mustard is harvested by removing the crop from the soil; hence introduces oxygen to the soil which then encouraged soil respiration. In contrast. pine-apple and grass are harvested by cutting the above ground part of the crops without disturbing the soil. Although scrub is never harvested. low plant density allows sun light to reach the soils. causing an increase in soil temperature. which subsequently also enhance soil respiration.

The low $\mathrm{CO}_{2}$ emissions from pine apple field strengthen the potential of pine apple to be developed along with tree for restoration efforts mentioned earlier. Local people of South Kalimantan consider pine apple as fire-belt crop because it can limit fire expansion during land fire. This is because the pineapple water contain is high (Onggo and Astuti. 2005). Therefore. the inclusion of pineapple in peat restoration ought to help to control land and forest fires that frequently occur in Kalimantan.

\section{CONCLUSIONS}

Most of the agricultural crops were classified as marginally suitable (Class S3), except Mustard (Class N) and coconut palm (Class S2). The main limiting factors of agricultural development in this area are low 
soil $\mathrm{pH}$, low base saturation and peat ripening. Peat depth limits the development of some crops. The above mentioned limiting factors ought to contribute to the low crop productivities in the area. Less limiting factor is encountered by pineapple. Addition of rice-husk biochar or sludge did not reduce $\mathrm{CO}_{2}$ emissions from the studied area. Instead of soil ameliorant application, selection of plant type seemed to be more promises in reducing $\mathrm{CO}_{2}$ emissions. Pineapple is potentially grown along with trees for peat restoration efforts.

\section{ACKNOWLEDGEMENT}

The authors acknowledge Dr. Jay P. Sah of Florida International University (USA) for valuable suggestions and English corrections. The helps of Ms. Syarifah Noor Farah (laboratory staff of Lambung Mangkurat University, Indonesia) during the laboratory works are also acknowledged.

\section{REFERENCES}

Anonym ${ }^{\mathrm{a}}$. 2016: Government Regulation No 57 Year 2016 on Protection and Management of Peatland Ecosystems. http/peraturan.go.id/pp/nomor-57-tahun2016.html. Accessed: 31 October. 2018. Anonym $^{\text {. }}$ 2016: Presidential Regulation No 1 Year 2016 on Peat Restoration Agency of

Indonesia.https://www.hukumonline.co $\mathrm{m} /$ pusatdata/downloadfile/lt56b1e9861e b21/parent/lt56b1e9013b10a. Accessed: 31 October. 2018.

Charmenta. R.. Zabala. A. and Phelps. J. 2015 :

http://www.cifor.org/publications/pdf_fi

Journal of Wetlands Environmental Management Vol 7, No 2 (2019) 115 - 122 http://dx.doi.org/10.20527/jwem.v7i2.187 les/ flyer/5882-flyer.pdf. Accessed: 15 April. 2019.

Bloem. J.. Hopkins. D.W. and Benedetti. A. 2006. Microbiological Methods for Assesing Soil Quality. CABI Publishing. Cambridge. USA.

Djaenudin. D.. Marwan H.. Subagjo H.. dan A. Hidayat. 2003: Technical Guidance in Land Evaluation for Agricultural Crops. Bogor. 154 p. (in Indonesian).

Hadi. A.. Hamdani. F.. Elma. M.. Ariffin. YF.. Fitrial. A.. Noor. MA.. Kumalawati. R.. Winarni. E.. Akbar. J.. Rianawati. F.. Mariana. ZT.. Rahmiyati. 2017: Final Report: Pilot Project on Integrated Peat Restoration in Liang Anggang Conserved Forest. South Kalimantan. Banjarbaru. 77 p. (in Indonesia)

Hadi. A.. Nohoi. G.. Ariffin. Inubushi. K. 1999: Status and availability of potassium to rice plant in tidal swamp soil in the tropics. Journal of Tropical Agriculture. 43.

Mathur. S.P. and Farham. R.S. 1985. Geochemistry of humic substances in natural and cultivated peatlands. In Aiken et al. (eds). Humic Substances in Soil. Sediment. and Water. John Wiley and Sons. Singapore. p. 53-85.

Mattjik. A.A.. and Sumertajaya. M. 2002: Experimental Design with SAS and Minitab Applications. IPB Press. Bogor (in Indonesian).

Onggo. H.dan Astuti. J.T. 2005: Effect of Sodium Hydroxide and Hydrogen Peroxide on Pulp Rendement and Colour of Pulp from Pineapple Leave. Jurnal Ilmu dan Teknologi Kayu Tropis. 3. 1-7 (in Indonesian). 
Page AL. Miller RH. Keeny DR. 1982:

Method of Soil Analysis. Amer. Soc. of Agronomy. Inc.. Wisconsin.

Syam'ani. Fithria .A. and Prihatiningtyas' E. 2018: Wetlands of Banjarbaru City in Last Four Decades. J. of Wetlands Env. Manag.. 6. 131-138. DOI: 10.20527/jwem.v6i2.183.
Warren. M.. Frolking. S.. Dai. Z. and Kurnianto. S. 2017: Impacts of land use. restoration. and climate change on tropical peat carbon stocks in the twenty-first century: implications for climate mitigation. Mitig Adapt Strateg Glob Change. 22. 1041-1061. DOI: 10.1007/s11027-016-9712-1. 